\title{
ADMINISTRATĪVĀS ATBILDĪBAS LIKUMA PAMATNOTEIKUMU SVARİGĀKĀS NOSTĀDNES
}

\section{IMPORTANT NOTIONS OF BASIC PROVISIONS OF ADMINISTRATIVE LIABILITY LAW}

\author{
Edvīns Danovskis, Dr. iur.
}

Latvijas Universitātes Juridiskās fakultātes

Valststiesību zinātṇu katedras docents

\section{Summary}

Administrative Liability Law, adopted in 2018, is intended to replace the Code of Administrative Offences. Although the new law retains a significant continuity with the existing regulation, it has many improvements. This article analyses four important notions incorporated in the basic provisions of the new law: the concept of culpability, punishment for several administrative offences, including repetitiveness, principle that administrative offences should not be used in area of private law and the concept of minor administrative offence.

Atslēgvārdi: vainojamība, atkārtotība, administratīvo pārkāpumu daudzējādība, maznozìmīgs administratīvs pārkāpums

Keywords: culpability, repetitiveness, multiplicity of administrative offences, minor administrative offence

\section{Ievads}

2018. gada nogalē pieņemtais Administratīiās atbildības likums ${ }^{1}$ (turpmāk AAL) ir radīts, pārņemot Latvijas Administratīvo pārkāpumu kodeksa (turpmāk - LAPK) darbības laikā uzkrāto pieredzi un pilnveidojot vairākus administratīvās atbildības institūtus. Likuma lasītāji pamanīs būtiskas izmaiņas likuma struktūrā (vairs nav sevišķās daļas), sodu reglamentācijā (ieviestas naudas soda vienības, vairs nav administratīvā aresta u. c.) un atsevišḳu procesuālo darbību izklāstā. Šādas izmaiṇas ir viegli pamanāmas un ātri saprotamas. Šā raksta mērḳis ir izgaismot tās fundamentālās izmaiņas likumā, kuras slēpjas vien dažos vārdos vai pat likuma tekstā vispār nav ietvertas, bet ņemtas vērā likuma radīšanā. Vairums šajā rakstā minēto jauninājumu ir tiesību zinātnē iepriekš izteikto atziṇu ìstenojums, tādēl raksts zināmā mērā arì popularizē tiesību zinātnes sasniegto administratìvo sodu tiesību jomā. Rakstā analizētas četras svarīgas nostādnes, kas izriet no administratīvās atbildības pamatnoteikumiem: atteikšanās no līdzšinējās vainas izpratnes un no administratīvo pārkāpumu daudzējādības veidiem,

1 Administratīvās atbildības likums: LV likums. Pieņemts 25.10.2018. 
administratīvo pārkāpumu sastāvu veidošanas principi un maznozīmīga administratīvā pārkāpuma institūtā ietvertā jēga. Šo nostādṇu pareiza izpratne ir būtiska kā likuma piemērošanā, tā administratīvo pārkāpumu sastāvu jaunradē.

\section{Vainojamības jēdziena ieviešana administratīvo pārkāpumu tiesībās}

Viena no fundamentālākajām izmaiṇām AAL ir atteikšanās no vainas un tās veidu formulējumiem, to aizstājot ar vainojamības jēdzienu. Šīs izmaiṇas bija neizbēgamas, jo jau LAPK darbības laikā vainas jēdzienam administratīvo pārkāpumu tiesībās nozīme faktiski bija zudusi.

Vainai un tās formām ir liela nozīme krimināltiesībās. Ja persona ir izdarījusi noziedzīgu nodarījumu, kura sastāvā ietilpst arī kaitīgas sekas (sabojāta manta, kaitējums dzīvībai, veselībai, videi u. tml.), tad personas psihiskā attieksme pret kaitīgajām sekām ir izšķiroša, lai nodarījumu kvalificētu pareizi (piemēram, nosakot, vai nonāvēšana ir tīša (slepkavība) vai aiz neuzmanības). Savukārt, ja noziedzīgajam nodarījumam ir formāls sastāvs (nodarījums ir pabeigts ar darbības vai bezdarbības izdarīšanu (piel̦aušanu)), tad vainas formām šajā gadījumā ir tīri teorētisks raksturs. Jau 2007. gadā profesors Uldis Krastiņš pierādīja, ka "vainas formu konstrukcijām formālu sastāvu nodarījumos, ar kādām izlīdzamies mācību [..] literatūrā, ir tīri teorētisks raksturs".2 "Personas psihiskā attieksme pret viṇas izdarìto noziedzīgo nodarījumu ar formālo sastāvu aprobežojas ar nodarījuma kaitīguma apzināšanos, kas tiek radìts noteiktām ar likumu aizsargātām interesēm." 3 Šì nostādne pārṇemta arī Krimināllikumā, tajā ietvertajā vainas formu sistēmā nodarījumus ar formālu sastāvu traktējot kā izdarītus ar tiešu nodomu. ${ }^{4}$ Šìs nostādnes pamatā ir acīmredzama patiesība - nav iespējams, ka persona apzināti izdara kādu darbību vai arī neveic to, kas jāizdara, to nevēloties. ${ }^{5}$

Turpretim administratīvo pārkāpumu tiesībās materiālu sastāvu, tas ir, tādu, kuru pabeigtībai nepieciešamas arī kaitīgās sekas, nav. Līdz ar to arī nodarījumu kvalifikācijā vainas formām nav nozīmes. Vēl vairāk - ņemot vērā to, ka daudzu administratīvo pārkāpumu subjekti var būt kā fiziskas, tā juridiskas personas, ir skaidrs, ka juridiskas personas gadījumā par vainu kā psihisku attieksmi vispār nav iespējams runāt. ${ }^{6}$ Tādēl arī AAL vainas jēdziens un tā formu skaidrojumi nav ietverti, un tās vietā administratīvā pārkāpuma sastāvā lietots vainojamības jēdziens.

Vainojamība ir situācija, kurā administratīvo pārkāpumu izdarījusī persona nevar atsaukties uz juridiski nozīmīgiem apstākḷiem, kuru esība būtu pamats

2 Krastiņš U. Konceptuāli par vainu administratīvajās tiesībās. Grām.: Krimināltiesību teorija un prakse: viedokḷi, problēmas un risinājumi. 1998-2008. Rīga: Latvijas Vēstnesis, 2009, 90. lpp.

3 Krastiņš U. Vaina kā obligāts kriminālatbildības nosacījums. Grām.: Krimināltiesību teorija un prakse: viedokḷi, problēmas un risinājumi. 1998-2008. Rīga: Latvijas Vēstnesis, 2009, 82. lpp.

4 Sk.: Grozijumi Krimināllikumā: LV likums. Pien̦emts 13.12.2012.

5 Krastiņš U. Krimināllikuma 9. panta komentārs. Grām.: Krimināllikuma komentāri. Pirmā daḷa (1-VIII ${ }^{1}$ nodaḷa). U. Krastiņš, V. Liholaja. Rīga: Tiesu namu aǵentūra, 2015, 64. lpp.

6 Sk. arī LU Juridiskās fakultātes mācībspēku E. Danovska un U. Krastiṇa vēstuli Tieslietu ministrijai: Par administratīvo pārkāpumu procesa likumu. Grām.: Krastiņš U. Krimināltiesību teorija un prakse: viedokḷi, problēmas un risinājumi (2015-2017). Rīga: Tiesu namu aǵentūra, 2018, 193.-195. lpp. 
atbrīvot personu no atbildības. ${ }^{7}$ Tātad, ja vien darbỉba vai bezdarbība ir attiecināma uz konkrēto personu (vainojamības objektīvais elements), ir prezumējams, ka persona par attiecīgo darbību ir vainojama.

Principā personu nav taisnīgi sodìt un viņa nav vainojama, ja tai nebija objektīvas iespējas izvairīties no pārkāpuma izdarǐšanas, izṇemot gadijjumus, kad tiesību normas paredz tādu uzvedības standartu, kas uzliek atbildību arī par risku. ${ }^{8}$ Līdz šim nav apstrīdēti tādi vainojamību izslēdzoši apstākḷi kā nepārvarama vara, nepieskaitāmība, attaisnojama kḷūda faktisko apstākḷu novērtēšanā. ${ }^{9}$ Vainojamību izslēdzoši apstākḷi var atškirties fiziskām un juridiskām personām, jo atšḳiras šo subjektu spēja izvairīties no pārkāpuma izdarīšanas. ${ }^{10}$

AAL ietvertais vainojamības koncepts atbilst līdzšinējai tiesību piemērošanas praksei un atvieglo administratīvā pārkāpuma uztveri. Attiecībā uz paša administratīvā pārkāpuma esību nepieciešams konstatēt tikai to, ka konkrēta persona ir veikusi rīcību, par kuru paredzēts administratīvais sods, un nav apstākḷu, kas izslēgtu personas vainojamību. Vainojamību izslēdzošus apstākḷus iestāde konstatē administratīvo pārkāpumu lietas izskatīšanā, taču tieši pie administratīvās atbildības saucamās personas pienākums ir norādīt uz apstākḷiem, kas izslēdz tās vainojamību, ciktāl tos nevarēja konstatēt pati iestāde.

Administratīvo pārkāpumu tiesībās izzūdot vainas jēdzienam, jāatrisina arī jautājums par to, vai teorijā un praksē ir lietderīgi turpināt izmantot no krimināltiesībām pārṇemto noziedzīga nodarījuma sastāva elementu sistēmu, proti, objektu, objektīvo pusi, subjektu un subjektīvo pusi. Principā šai sistēmai ir tīri teorētisks raksturs - tā it kā atvieglo visu likumā minēto noziedzīga nodarījuma sastāva pazīmju uztveri. ${ }^{11}$ Taču administratīvo pārkāpumu tiesībās šāda iedalījuma lietošanai vairs nav pamata. Pirmkārt, nav nozīmes izšķirt kā administratīvā pārkāpuma elementu, tā objektu - visnotaḷ teorētisko "tiesiski aizsargājamo interesi", pret kuru vērsts administratīvs pārkāpums. Praksē šāda intereses konstatēšana nenotiek, jo ir pašsaprotama - ja persona izdara administratīvi sodāmu pārkāpumu, tad acīmredzot šāda darbība apdraud kaut kādas tiesiski aizsargājamas intereses. Otrkārt, objektīvās puses konstatēšana ir nekas cits kā personas veiktās darbības (bezdarbības) pakārtošana administrativo atbildỉbu paredzošās normas tiesiskā sastāva pazīmēm jeb subsumcija. Dēvēt personas paveikto rīcību (darbību vai bezdarbību) par objektīvo pusi škiet lieki, jo šādam terminam administratīvo pārkāpumu tiesībās nav dziḷākas jēgas. Treškārt, ja vispār administratìvo pārkāpumu tiesībās teorētiski var runāt par subjektīvo pusi, tad katrā ziṇā ar citu saturu nekā krimināltiesībās, kur subjektīvo pusi veido fiziskas personas psihiskā attieksme pret nodarījumu. ${ }^{12}$ N̦emot vērā administratīvā pārkāpuma ḷoti vienkāršo

7 Danovskis E. Juridisko personu administratīvā atbildība Latvijā: problēmas un pilnveidošanas iespējas. Grām.: Autoru kolektīvs. Juridisko personu publiski tiesiskā atbildība: aktualitātes, problēmas un iespējamie risinājumi. Rīga: LU Akadēmiskais apgāds, 2018, 160. lpp.

8 Sk.: ibid., 161. lpp.

9 Sk.: Danovskis E. Apstākḷi, kas atbrīvo no administratīvās atbildības. Grām.: Latvijas Republikas Satversmei - 95. Latvijas Universitātes 75. zinātniskās konferences rakstu krājums. Rīga: LU Akadēmiskais apgāds, 2017, 372.-375. lpp.

10 Sk.: Danovskis E. 2018, 161.-162. lpp.

11 Par noziedzīga nodarījuma sastāva nozīmi krimināltiesībās sk., piemēram: Vaina kā obligāts kriminālatbildības nosacījums. Grām.: Krimināltiesību teorija un prakse: viedokḷi, problēmas un risinājumi. 1998-2008. Rīga: Latvijas Vēstnesis, 2009, 78.-79. lpp.

12 Krastiņš U. Noziedzīga nodarījuma sastāvs un nodarījuma kvalifikācija. Teorētiskie aspekti. Rīga: Tiesu namu aǵentūra, 2014, 32. lpp. 
uzbūvi un AAL ietverto administratīvā pārkāpuma jēdzienu, noziedzīga nodarījuma sastāva elementu attiecināšana uz administratīviem pārkāpumiem no teorētiskā viedokḷa nav attaisnojama. Terminoloǵiski ir iespējams lietot visnotaḷ parocīgo jēdzienu "administratīvā pārkāpuma subjekts", ar to raksturojot tās likumā ietvertās pazīmes, kas attiecas uz administratīvā pārkāpuma izdarītāju.

\section{Atteikšanās no administratīivo pārkāpumu daudzējādības veidiem}

AAL vairs nereglamentē administratīvo pārkāpumu daudzējādības veidus administratìvo pārkāpumu atkārtotību un kopỉbu.

LAPK Sevišḳajā daḷā ir paredzēti diezgan daudzi administratīvo pārkāpumu sastāvi ar kvalificējošu pazīmi: "ja pārkāpums izdarīts atkārtoti gada laikā pēc administratīiā soda uzlikšanas". Šis vēl no padomju krimināltiesībām aizgūtais daudzējādības veids bija mēginājums obligāti paredzēt bargāku sodu par atkārtoti izdarītu pārkāpumu. Taču ši pārkāpumu daudzējādības veida piemērošana varēja radīt problēmas gadījumos, kad lēmums par pirmā pārkāpuma izdarīšanu bija pārsūdzēts un pārsūdzības laikā persona bija izdarỉjusi jaunu pārkāpumu. Ja otrais pārkāpums tiktu kvalificēts pēc atkārtotības pazìmes, bet pirmais pārsūdzības rezultātā tiktu atcelts, nāktos pārskatīt arī otru lēmumu. Pārkāpumu atkārtotība bija apšaubāma arī dubultās sodīšanas aizlieguma principa kontekstā. Arguments, ka noziedzīgi nodarījumi ar atkārtotību kā sastāva pazīmi pārkāpj dubultās sodīšanas aizlieguma principu, tika izmantots, lai šo daudzējādỉbas veidu 2012. gadā izslēgtu no Krimināllikuma. ${ }^{13}$ Atkārtotības kā administratīvo pārkāpumu daudzējādības veida lietderība bija apšaubīta jau 2011. gadā, jo šādu kvalificējošu sastāvu veidošana nevajadzīgi palielina likuma tekstu, un atkārtotību var ņemt vērā, nosakot sodu. ${ }^{14}$ Ievērojot šos apsvērumus, AAL 22. panta pirmā daḷa noteic šādi: "Ja viena persona izdarījusi divus vai vairākus administratīvos pārkāpumus, administratīvo sodu piemēro par katru pārkāpumu atsevišksi." Tas nozīmē, ka vairs nav piel̦aujams veidot tādus administratīvo pārkāpumu sastāvus, kuros ir ietverta atkārtotības pazīme.

Faktu, ka administratīvās sodāmības laikā ir izdarīts tāds pats vai līdzìgs pārkāpums, turpmāk ir iespējams (bet nav nepieciešams) ņemt vērā, nosakot sodu. Ja persona administratīvās sodāmības laikā ir izdarījusi tādu pašu vai līdzìgu pārkāpumu, tad ir iespējams secināt, ka iepriekš piemērotais sods nav sasniedzis soda mērḳi - pārkāpumu prevenciju attiecībā uz sodīto personu. Šādā gadījumā, nosakot sodu par vēlāk izdarīto pārkāpumu, iestāde var ņemt vērā, ka jaunā pārkāpuma raksturs liecina par to, ka nepieciešams piemērot bargāku administratīvo sodu.

LAPK 35. panta otrajā dạ̄ā ir ietverts šāds noteikums: "Ja persona ir izdarījusi vairākus administratīvos pārkāpumus, kas konstatēti vienlaicīgi, un tos izskata viena un tā pati institūcija (amatpersona), administratīvais sods tiek uzlikts tās sankcijas ietvaros, kura ir paredzēta par smagāko pārkāpumu.” Šì norma paredzēja, ka soda apmērs var atšksirties atkarībā no piekritīgās institūcijas un tā, vai pārkāpums tiek konstatēts vienlaikus. Šāds noteikums radīja nepamatoti atšķirīgus soda uzlikšanas noteikumus - nav saprātīga iemesla, kādēḷ soda apmēram

13 Sk.: likumprojekta “Grozījumi Krimināllikumā” anotācija. Pieejams: http://titania.saeima.lv/LIVS11/ SaeimaLIVS11.nsf/0/F8EAF0BB07FCB67AC225793300488419?OpenDocument [aplūkots 20.03.2019.].

14 Sk.: Danovskis E. Administratīvās atbildības regulējuma konceptuālās problēmas. Jurista Vārds, 17.05.2011., Nr. 20 (667). 
vajadzētu būt mazākam situācijā, kad pārkāpumu izskatīšana ir piekritīga vienai institūcijai, bet lielākam - ja pārkāpumu izskatī̌sana ir piekritīga atšķirīgām institūcijām. Ievērojot šos apsvērumus, AAL ir ietverts princips - "viens pārkāpums, viens sods. [..] ja persona vienlaikus izdara vairākus pārkāpumus, galīgais sods ir lielāks, nekā tad, ja izdarīts tikai viens pārkāpums. Tādejādi tiek panākts taisnīgāks gala rezultāts. Bez tam šāda soda noteikšana, domājams, būs vienkāršāka un saprotamāka ne tikai pārkāpuma izdarītājam, bet arī amatpersonām, kam jānosaka sods par vairākiem izdarītajiem pārkāpumiem". ${ }^{15}$

\section{Administratīvo pārkāpumu sastāvu veidošanā ievērojamie principi}

Administratīvās atbildības regulējuma reformas ietvaros notiek tā sauktā administratīvās atbildības regulējuma dekodifikācija, administratīvo pārkāpumu sastāvus nosakot nevis AAL, bet gan citos likumos. Gan šajā procesā, gan turpmāk administratīvo pārkāpumu sastāvu veidošanā nepieciešams ievērot divus principus: nevajag paredzēt administratīvo atbildību par prettiesisku rīcību privāto tiesību jomā un administratīvo atbildību par iestādes izdoto administratīvo aktu neizpildīšanu. Abi no šiem principiem sākotnēji ir formulēti tiesību zinātnē. Šajā rakstā atgādināts to pamatojums un uzsvērta nepieciešamība tos konsekventi ievērot.

Jau 2012. gadā Valsts kancelejas pasūtītajā pētījumā par administratīvā procesa efektivizēšanas iespējām secināts, ka "subjektīvo privāto tiesību aizsardzība visupirms ir panākama prasības tiesvedības kārtībā pēc aizskartās personas iniciatīvas. Tādēl [..] valstij nav lietderīgi iejaukties tad, ja strīds jau tiek risināts Civilprocesa likumā noteiktajā kārtībā. Valstiskā iejaukšanās principā nepieciešama tikai tad, kad kāds pārkāpums var skart ievērojamu sabiedrības dal̦u". ${ }^{16}$ Līdzīgi secinājumi izteikti arī 2013. gadā apstiprinātajā Administratīvo sodu sistēmas attīstības koncepcijā ${ }^{17}$ un atkārtoti 2016. gadā piencemtajā informatīvajā ziṇojumā, kurā kā viens no principiem administratīvo pārkāpumu sastāvu veidošanā formulēts šāds: "nodarījuma attiecināmība uz publiski tiesiskajām attiecībām (proti, vai kodeksā noteiktie administratīvie sodi ir paredzēti par civiltiesisku saistību pārkāpšanu un līdz ar to nav saglabājami; vai kodeksā noteiktie administratīvie sodi, kas uzskatāmi par valsts iejaukšanos civiltiesiskajās attiecībās, ir attaisnojami, jo aizskar būtiskas sabiedriskās intereses (piemēram, darba tiesībās, patērētāju aizsardzības tiesībās) un līdz ar to saglabājami u. tml.)" ${ }^{18}$

Administratīvās atbildības regulējums nav paredzēts civiltiesisku strīdu risināšanai. Ja privātpersonai ir iespējams savas aizskartās tiesības aizstāvēt ar civiltiesiskās aizsardzības līdzekḷiem, tad par attiecīgu privāttiesiskas attiecības regulējošo normu neievērošanu administratīvo atbildību likumā nevajag paredzēt. Izṇēmumi

15 Administratīivo pārkāpumu procesa likuma anotācija. Pieejams: http://titania.saeima.lv/LIVS12/SaeimaLIVS12.nsf/0/8F85FC1AE272C759C2257D8E004788AD?OpenDocument [aplūkots 20.03.2019.].

16 Administratīvā procesa likuma ieviešanas ietekmes izvērtējums un efektivizēšanas priekšlikumu izstrāde - gala ziņojums, 55. lpp. Pieejams: https://www.mk.gov.lv/sites/default/files/editor/2zinojums_ apl_11junijs_0.pdf [aplūkots 20.03.2019.].

17 Administratīivo sodu sistēmas attīstības koncepcija, 24. lpp. Pieejams: http://polsis.mk.gov.lv/api/file/ file2478.doc [aplūkots 20.03.2019.].

18 Informatīvais ziṇojums "Nozaru administratīvo pārkāpumu kodifikācijas ieviešanas sistēmas ìstenošana”, 2. lpp. Pieejams: http://tap.mk.gov.lv/doc/2016_12/TMZino_071116_adpark.2498.docx [aplūkots 20.03.2019.]. 
var būt jomās, kurās prettiesiskā rīcība skar plašu, neidentificējamu personu loku, piemēram, patērētāju aizsardzības tiesības.

Pārskatot līdz šā raksta tapšanai Saeimā tā sauktās dekodifikācijas ietvaros iesniegtos likumprojektus, vēl joprojām atrodami gadījumi, kad administrativāà atbildība paredzēta par prettiesiskām darbībām privāto tiesību jomā. Piemēram, likumprojektā "Grozījums Dzivojamo māju pārvaldīšanas likumā” atrodams šāds administratīvā pārkāpums sastāvs: "Par izvairī̌sanos no likumā noteikto obligāti veicamo pārvaldīšanas darbību veikšanas uzliek naudas sodu - dzīvojamās mājas īpašniekam vai pārvaldniekam [..]."19 Saeimas Juridiskais birojs atzinumā par šo likumprojektu norādījis, ka minētajā normā "tiek noteikts administratīvs sods par to, ka īpašnieks neveic pārvaldīšanas darbības pats savā īpašumā. Tā, piemēram, paredzēts, ka administratīvi sodāma ir izvairīšanās no mājas uzturēšanai nepieciešamā attiecīgā gada budžeta projekta sagatavošanas vai izvairišanās no civiltiesiska līguma noslēgšanas ar zemes īpašnieku”. ${ }^{20}$ Nejēdzīgi plašs ir arī likumprojektā "Grozījumi Darba likumā" paredzētais administratīvā pārkāpuma sastāvs: "Par darba tiesiskās attiecības regulējošo normatīvo aktu pārkāpšanu [....” Arī nepamatota atbrīvošana no darba ir "darba tiesiskās attiecības regulējošo normatìvo aktu pārkāpums", taču darbiniekiem jau ir paredzēts efektīvs tiesiskās aizsardzības līdzeklis - prasības pieteikums tiesā par darba devēja uzteikuma atzī̌anu par spēkā neesošu. Valsts darba inspekcijas piemērots administrativvais sods šādā gadījumā būtu nepamatota valsts iejaukšanās privāttiesiskās attiecībās.

Administratīvo pārkāpumu sastāvus nevajadzētu paredzēt arī par administrativvo aktu neizpildǐšanu. Lìdz šim LAPK bija ietverts gan $175 .{ }^{2}$ pants (atbildỉba "par kontroles, uzraudzības vai izmeklēšanas funkcijas realizējošo valsts vai pašvaldïbas institūciju amatpersonu likumīgo prasību savlaicīgu neizpildīšanu”), gan citi panti, kuros noteikta administratīvā atbildība par administratīvo aktu nepildīšanu. Administratīvā akta izpilde ir "panākama ar procesuālajiem piespiedu līdzekḷiem administratīvā procesa ietvaros, nevis konstruējama kā atsevišķs administratīvā pārkāpuma sastāvs, kas turklāt tiek skatīts citā tiesā un citā procesuālā kārtībā" ${ }^{21}$ Tādēl arī Ministru kabineta apstiprinātajā informatīvajā ziṇojumā ir īpaši uzsvērts: “[..] ir aizliegts paredzēt administratīvos sodus par administratīvā akta labprātīgu neizpildīšanu. Proti, ja lieta uzsākta administratīvā procesa ietvaros, tad šì procesa ietvaros tā arī ir jāpabeidz. Administratīvā procesa likuma astotajā sadaḷā ir noteikta administratīvā akta izpildes kārtība, tai skaitā piespiedu izpildes kārtība. Līdz ar to gan šajā administratīvajā procesā izdotais administratīvais akts, gan tā izpildē veiktās faktiskās darbības ir pakḷautas administratīio tiesu kontrolei un veido vienu saturiski un loǵiski vienotu procesu." ${ }^{22}$ Tāds pats secinājums atkārtots

19 Grozījums Dzīvojamo māju pārvaldī̌anas likumā: LV likums. Pieejams: http://titania.saeima.lv/ LIVS12/saeimalivs12.nsf/0/8369B34C9B82EEB5C2257F7D0030D584?OpenDocument [aplūkots 20.03.2019.].

20 Saeimas Juridiskā biroja 27.02.2019. atzinums Nr. 111.13/1-45-13/19 par likumprojektu “Grozijumi Dzīvojamo māju pārvaldīšanas likumā”. Pieejams: https:/titania.saeima.lv/LIVS13/saeimalivs13.nsf/ 0/64B05B7F15406958C22583B300317233?OpenDocument [aplūkots 20.03.2019.].

21 Administrativā procesa likuma ieviešanas ietekmes izvērtējums un efektivizēšanas priekšlikumu izstrāde - gala ziņojums, 68.-69. lpp. Pieejams: https://www.mk.gov.lv/sites/default/files/editor/ 2zinojums_apl_11junijs_0.pdf [aplūkots 20.03.2019.].

${ }^{22}$ Informatīvais ziņojums "Nozaru administratīvo pārkāpumu kodifikācijas ieviešanas sistēmas īstenošana”, 2. lpp. Pieejams: http://tap.mk.gov.lv/doc/2016_12/TMZino_071116_adpark.2498.docx [aplūkots 20.03.2019.]. 
arī 2018. gada nogalē apstiprinātajā informatīvajā ziṇojumā. ${ }^{23}$ Augstākā tiesa ir uzsvērusi, ka "arī šobrīd administratīvās atbildības piemērošana minētajos gadījumos neveido saturiski un logiski vienotu procesu, tādējādi apdraudot tiesisko noteiktību un skaidrību. Lìdz ar to Senāts vērš iestādes uzmanību uz to, ka lietās par pienākuma nepildī̌sanu, kas ir uzlikts ar administratīvo aktu, šā pienākuma izpildi būtu jācenšas panākt, piemērojot Administratīvā procesa likumā noteiktos piespiedu izpildes līdzekḷus (piemēram, piespiedu naudu), nevis piemērojot administratīvo atbildību. Gan administratīvais akts, gan arī strīdi par tā izpildi ir pakḷauti administratīvās tiesas kontrolei, kas nodrošina šā procesa efektivitāti un izslēdz paralēlus procesus par vieniem un tiem pašiem faktiskajiem apstākḷiem dažādu jurisdikciju tiesās". ${ }^{24}$ No iepriekš minētā izriet akūta nepieciešamība administratīvo pārkāpumu sastāvu izstrādē ievērot minētos principus, jo to neievērošana likuma līmenī noved pie sistēmiski nepareiza regulējuma, bet piemērošana praksē rada sodīšanu tur, kur tā nav vajadzīga, un paralēlus tiesvedỉbas procesus.

\section{Administratīiā pārkāpuma atzīšana par maznozīmīgu}

AAL 11. panta pirmajā daḷā ir ietverts pareizai administratīvās atbildības izpratnei fundamentāli svarīgs noteikums: "Ja personas izdarītais administratīvais pārkāpums konkrētajos apstākḷos nav radījis tādu apdraudējumu tiesiski aizsargātajām interesēm, lai par to piemērotu sodu (maznozīmīgs pārkāpums), amatpersona var neuzsākt administratīvā pārkāpuma procesu, bet, ja tas ir uzsākts, amatpersona, augstāka amatpersona vai tiesa jebkurā stadijā var to izbeigt, nepiemērojot sodu. Šajā gadijumā amatpersona, augstāka amatpersona vai tiesa, ja to atzīst par lietderīgu, izsaka personai aizrādījumu. Aizrādījums nerada tiesiskas sekas." Iespēja atzīt administratīvo pārkāpumu par maznozīmīgu bija ietverta arī LAPK 21. pantā. AAL ietvertajā normā precīzāk formulēta šì institūta būtība: nepārprotami uzsvērt, ka iestādei ir rīcības brīvība lemt, vai administratīvā sodīšana konkrētā gadījumā ir vai nav lietderīga.

Krimināltiesībās soda neizbēgamības princips ir ārkārtīgi svarīgs. Ja ir izdarīts noziedzīgs nodarījums, tad prasība pēc soda izriet no taisnīguma principa. Nav taisnīgi nesodìt to, kurš, izdarot noziedzīgu nodarījumu, nodarījis kaitējumu cita dzīvībai, īpašumam, videi u. c. būtiskām interesēm. Turpretim administratīvo pārkāpumu tiesībās soda neizbēgamība nav princips, jo administratīvā sodīšana ir juridisks instruments, lai valsts pārvalde varētu pienācīgi īstenot izpildvaras funkcijas. Atšķirībā no krimināltiesībām administratīvo pārkāpumu sastāvi nav uzskatāmi par likumdevēja pavēli sodīt katru, kurš izdarījis administratīvu pārkāpumu. Tas nav nedz iespējams, nedz lietderīgi. Ir vispārzināms, ka ik dienas tiek izdarīts milzīgs skaits nefiksētu administratīivu pārkāpumu (piemēram, transportlīdzekḷa apstādināšana neatḷautā vietā, īslaicīga maksimālā braukšanas ātruma pārsniegšana utt.), taču diez vai kāds apgalvos, ka par katru no šiem pārkāpumiem būtu taisnīgi un lietderīgi sodīt. Tādēl administratīvo pārkāpumu kodeksā nav ietverts Kriminālprocesa likuma 6. pantā ietvertajam kriminālprocesuālā

${ }^{23}$ Informatīvais ziṇojums "Nozaru administratīvo pārkāpumu kodifikācijas ieviešanas sistēmas īstenošana”, 2. lpp. Pieejams: http://tap.mk.gov.lv/doc/2018_12/TMZin_101218_kod.2623.docx [aplūkots 20.03.2019.].

24 Augstākās tiesas Senāta Administratīvo lietu departamenta 15.02.2019. lēmums lietā Nr. SKA-946/2019, 6. punkts. Pieejams: https://manas.tiesas.lv/eTiesasMvc/nolemumi/pdf/375960.pdf [aplūkots 20.03.2019.]. 
obligātuma principam līdzīgs princips. Līdz ar to arī iestādei, saṇemot ziṇas par iespējamu administratīvu pārkāpumu, ir rīcības brīvība izvērtēt, vai administratīvā pārkāpuma lietvedība konkrētajā situācijā ir lietderīga. No AAL 11. panta arī izriet pēdējā laikā arvien lielāku popularitāti ieguvušais sauklis "konsultē/brīdini, pirms sodi".

AAL 11. pantā nepārprotami noteikts, ka mutvārdu aizrādījuma izteikšana nerada tiesiskas sekas. Lìdz ar to persona, kurai izteikts mutvārdu aizrādījums, nav tiesīga šo mutvārdu aizrādījumu pārsūdzēt. Agrāk tiesu praksē nereti bija sastopami kḷūdaini spriedumi, kuros tiesas bija vērtējušas arī mutvārdu aizrādījuma tiesiskumu. ${ }^{25}$ AAL nepārotami noteic, ka šajos gadījumos personai nav subjektīvo tiesību iebilst pret mutvārdu aizrādījuma izteikšanu, jo šāds aizrādījums pats par sevi neaizskar personas tiesības vai tiesiskās intereses.

\section{Kopsavilkums}

1. Administratīvo pārkāpumu definīcijā ietvertais vainojamības jēdziens paredz: ja vien darbība vai bezdarbība ir attiecināma uz konkrēto personu, tad ir prezumējams, ka persona par attiecīgo darbỉbu ir vainojama. Personu nav taisnīgi sodìt un viņa nav vainojama, ja tai nebija objektīvas iespējas izvairīties no pārkāpuma izdarǐšanas.

2. Administratīvo pārkāpumu sastāvos turpmāk nav piel̦aujams paredzēt atkārtotību kā kvalificējošu sastāva pazīmi. Ja persona ir izdarỉjusi vairākus administratīvos pārkāpumus, tad sods par katru no tiem ir uzliekams atseviški.

3. Administratīvo pārkāpumu sastāvu veidošanā ievērojami divi tiesību zinātnē formulētie un Ministru kabineta akceptētie principi: nav piẹ̦aujams paredzēt administratīvo atbildību par prettiesisku rīcību privāto tiesību jomā un administrativo atbildỉbu par administratīvo aktu neizpildī̌anu.

4. Maznozīmīga administratīvā pārkāpuma institūta jēga ir piešḳirt iestādei rīcības brīvību lemt par to, vai administratīvā soda piemērošana (arī lietas ierosināšana) ir lietderīga. Administratīvo pārkāpumu tiesībās soda neizbēgamība nav princips.

25 Sk., piemēram: Rīgas rajona tiesas 22.09.2016. spriedums lietā Nr.133055116. Pieejams: https://manas. tiesas.lv/eTiesasMvc/nolemumi/pdf/296398.pdf [aplūkots 20.03.2019.]. 